\title{
The karst site of Las Palomas (Guadalteba County, Málaga, Spain): A preliminary study of its Middle-Late Pleistocene archaeopaleontological record
}

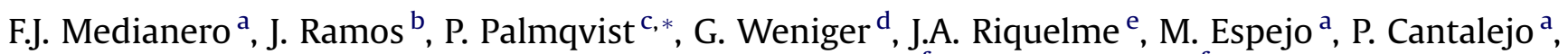 \\ A. Aranda a ${ }^{a}$ J.A. Pérez-Claros ${ }^{c}$, B. Figueirido ${ }^{c}$, P. Espigares $^{f}$, S. Ros-Montoya ${ }^{\text {f }}$, V. Torregrosa ${ }^{g}$, \\ J. Linstädter ${ }^{d}$, L. Cabello ${ }^{a}$, S. Becerra ${ }^{a}$, P. Ledesma ${ }^{a}$, I. Mevdev ${ }^{d}$, A. Castro $^{h}$, M. Romero ${ }^{\text {h }}$, \\ B. Martínez-Navarro ${ }^{\mathrm{i}}$ \\ a Escuela Taller Parque Guadalteba y Red Patrimonio Guadalteba, Área de Arqueología, Consorcio Guadalteba, Ctra. Campillos-Málaga, km 11, Campillos, 29320 Málaga, Spain \\ b Área de Prehistoria, Departamento de Historia, Geografia y Filosofia, Facultad de Filosofía y Letras, Universidad de Cádiz, Avda, Gómez Ulla, s/n, 11003 Cádiz, Spain \\ ${ }^{\mathrm{c}}$ Departamento de Ecología y Geología, Área de Paleontología, Facultad de Ciencias, Universidad de Málaga, Campus Universitario de Teatinos, 29071 Málaga, Spain \\ d Stiftung Neanderthal Museum, Talstrasse 300, D-40822 Mettmann, Germany \\ e Departamento de Prehistoria y Arqueología, Universidad de Granada, Campus Universitario de Cartuja, 18071 Granada, Spain \\ ${ }^{\mathrm{f}}$ Museo de Prehistoria y Paleontología de Orce, Palacio de Segura, 18858 Orce, Granada, Spain \\ ${ }^{\mathrm{g}}$ Fundación Geociencias E’ Art Natura Málaga, Avenida Sor Teresa Prat, 15, 29003 Málaga, Spain

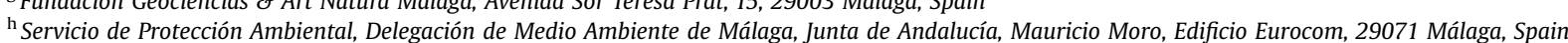

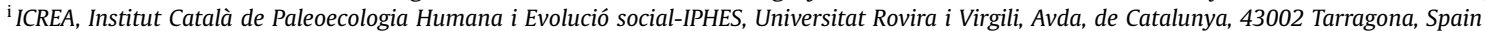

\section{A R T I C L E I N F O}

Article history:

Available online 7 January 2011

\begin{abstract}
A B S T R A C T
Cleaning works in the cave of Las Palomas in Teba (Málaga, Spain), developed by the Guadalteba Consortium, have provided a number of lithic tools and knapping products that may be ascribed to the Mode III technotypological tradition as well as remains of a number of large mammal species typical of Middle-Late Pleistocene times. Topographic measurements help to place this ancient cave within a karst landform. This discovery opens up new perspectives in the research on the Neanderthal groups that inhabited the valleys of Guadalteba and Turón rivers in the middle basin of the Guadalhorce River, and thus in the southern region of the Iberian Peninsula.
\end{abstract}

() 2011 Elsevier Ltd and INQUA. All rights reserved.

\section{Introduction}

Results obtained in the field work developed within the karst site of "Las Palomas" cave in Teba (Málaga, southern Spain) are discussed in this article. These works were promoted by the Guadalteba Consortium for assessing the archaeological heritage of Guadalteba County. The geographical location of the cavity is 332863/4094817 (UTM coordinates, European-1950 datum) and the height above the sea level is approximately $450 \mathrm{~m}$ (Figs. 1 and 2).

Field work, directed by F.J. Medianero, consisted of the cleaning and collection of archaeological and faunal records found on the surface after the intense pillaging of this cavity, as well as the clearing of the abundant sedimentary breccias of the karst complex. Cleaning works for conditioning the cavity started in the year 2002 and were intended to remove the abundant trash and the closing of

\footnotetext{
* Corresponding author.

E-mail address: ppb@uma.es (P. Palmqvist).
}

the entrances, except the exit to the canyon mentioned above. A way for pedestrian access was enabled and also a platform or scaffold of low environmental impact that allows the passage of materials and people. This platform will be used as a permanent installation in future works.

Cave topography, developed for locating the remains, provides an emerging view of the cavity, in which dissolution was the main agent responsible for generating a karst system of greater proportions than those known in the late twentieth century (Ferrer and Marques, 1978; Baldomero, 1978; Aguado and Baldomero, 1979; Fernández, 1986; Fontao, 1986; Ferrer and Fernández, 1988; Recio-Ruiz, 1993). Apart from the main cave, the complex includes a number of lateral galleries of unknown dimensions filled with sediment, a doline and a "Sima" or chasm, which allow study of the origin and development of this geological complex as well as the relationship of the human settlements with the local environment (Figs. 3 and 4).

Cleaning was made in two different areas: first, materials were collected outside the complex at UTM coordinates 332848/ 


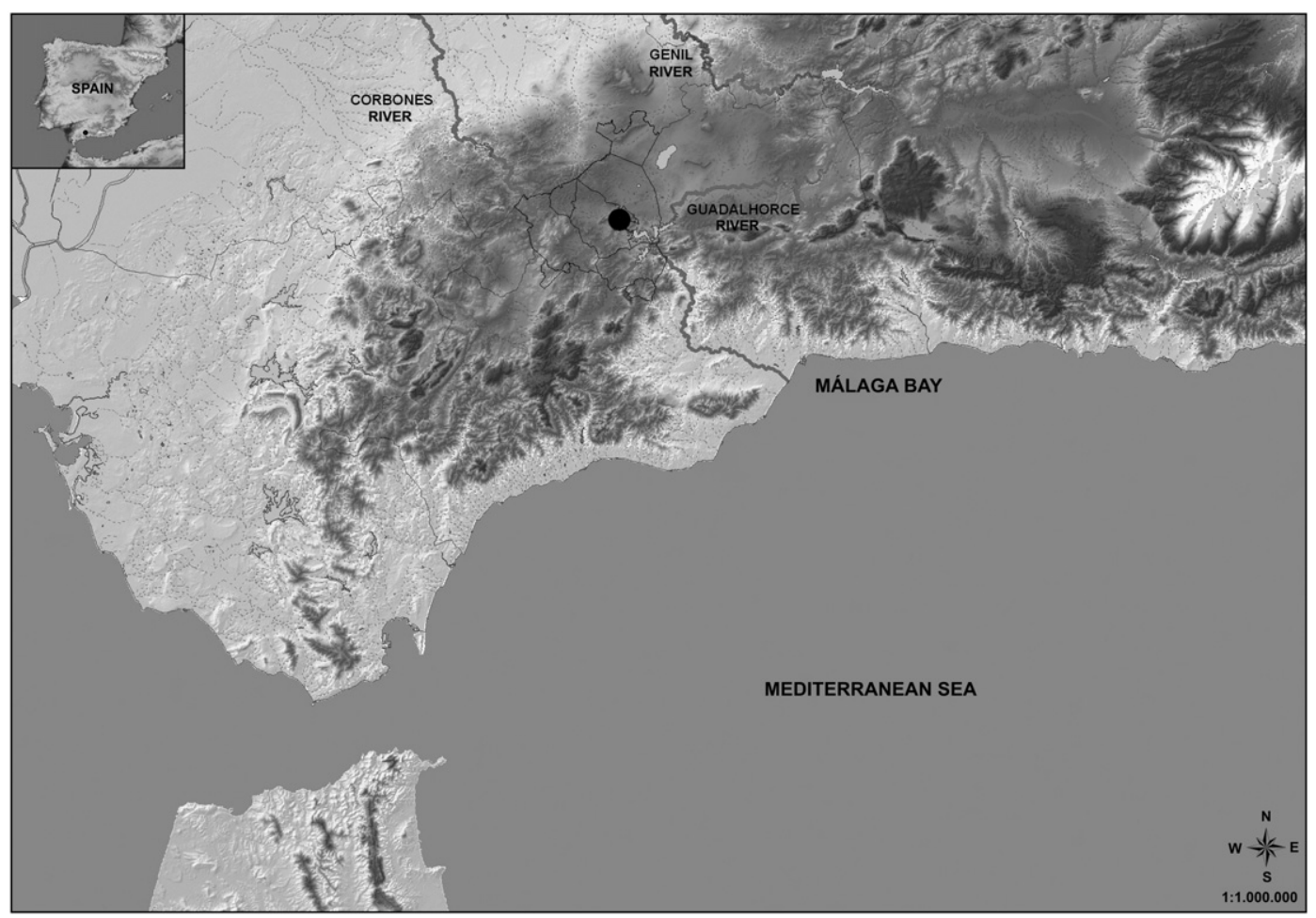

Fig. 1. Geographic location of "las Palomas de Teba" in the South of the Iberian Peninsula. The dotted circle indicates the position of the karst complex.

4094834, 332820/409469 and 332829/40947814 during cave conditioning. Second, materials were also documented inside the complex. The latter materials, which are the ones shown here, are interspersed with garbage of all kinds and with fragments resulting from the clearing of sedimentary breccias during the intense activities of spoliation experienced by the cave in the last thirty years (Medianero, 2003, 2007a, 2007b, 2008).

\section{Geological context and geographical location of the cave environment}

The karst complex of Las Palomas is located in the West Peñarrubia Mountains, close to La Venta River, in a place known as Tajo del Molino. It belongs to the district of Teba and hydrographically to the Guadalteba basin, a tributary of the Guadalhorce River.

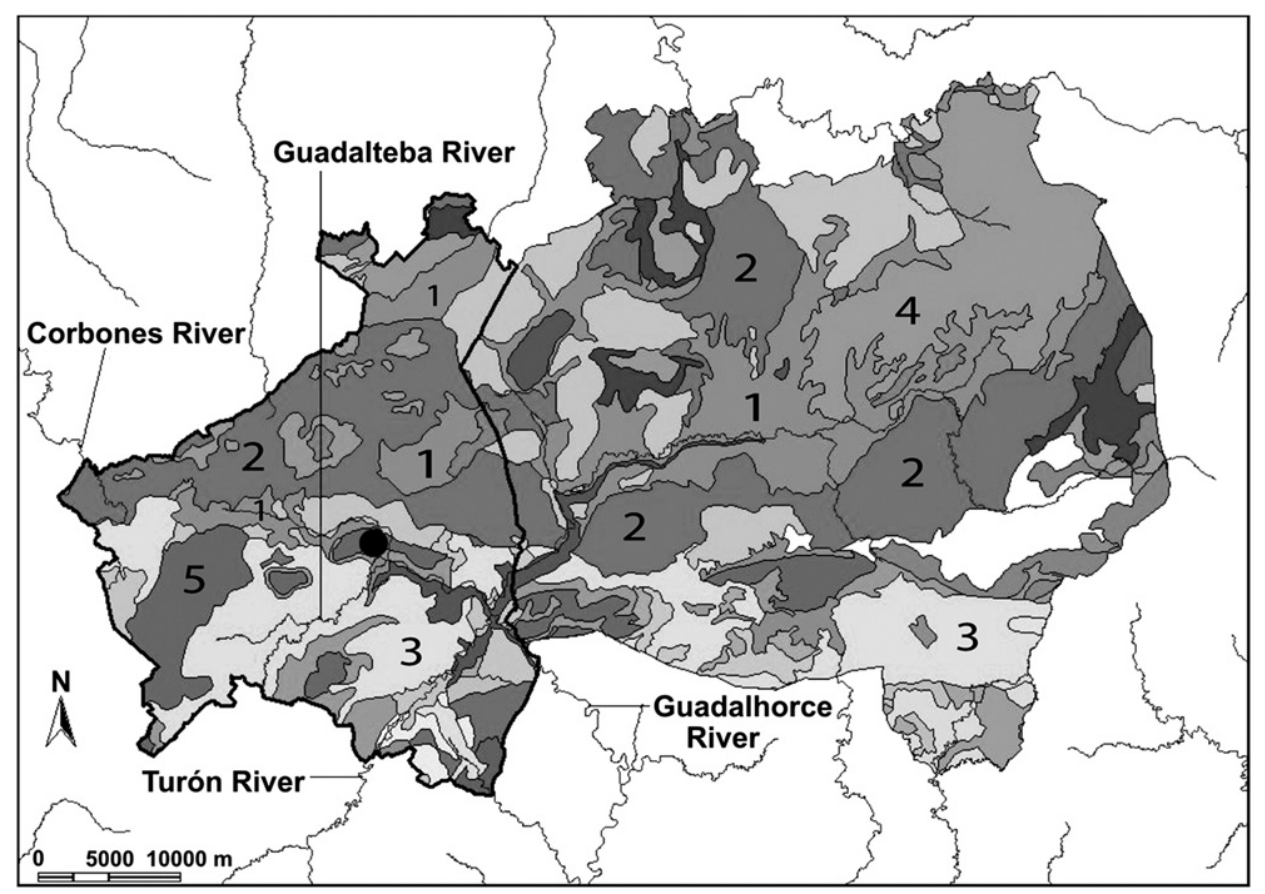

Fig. 2. Geological map of the Guadalteba County (the dotted circle indicates the position of the karst complex of Las Palomas de Teba). 1: Triassic conglomerates, sandstones and clays. 2: Triassic variegated clays, red sandstones, gypsum and limestones. 3: Early Miocene clays and marls. 4: Jurassic limestones, marls, limestones with flint and radiolarian marls. 5: Jurassic dolomites, limestones and limestones with flint. 


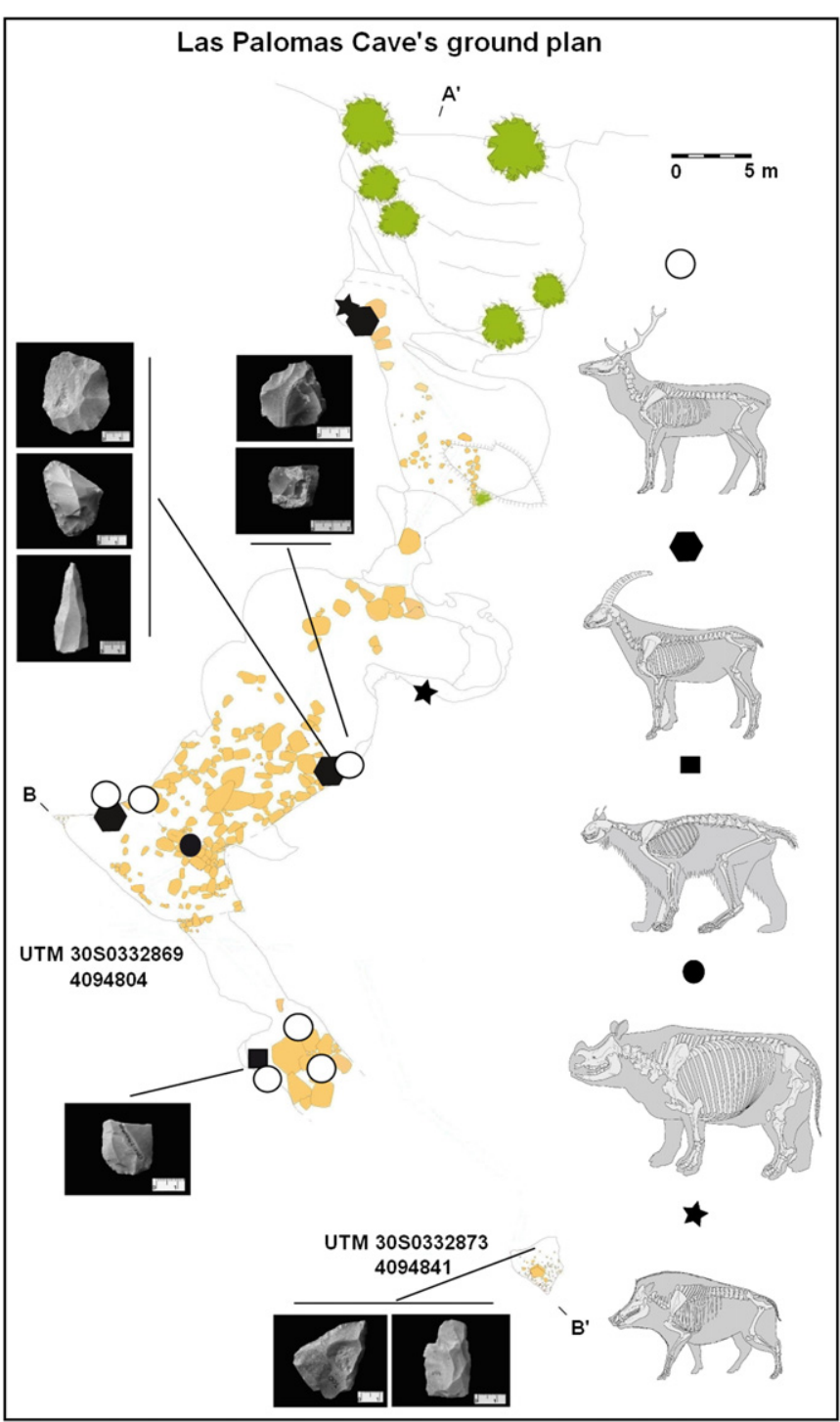

Fig. 3. Location of finds (lithic tools and large mammal remains) inside the karst complex.

This Andalusian area is located in the sector of the intrabetic ridge that corresponds to the western-central part of the province of Málaga and constitutes the transitional space from the Antequera basin to the Ronda basin and the Iberian plateau. The geographical setting is defined in the southern part by a mountainous alignment that crosses the province of Málaga from the southwest to the east and separates the inland from the coast. This cordillera is formed by Sierra Prieta (1524 m), Alcaparaín (1290 m) and Valle de Abdalajís $(1195 \mathrm{~m})$. The northern and eastern parts of the Guadalteba basin are connected with the valleys of the Genil and Guadalquivir rivers by the Guadalhorce River and a number of small streams that show abundant pools connecting the flat lands of Antequera and Campillos. The Guadalteba basin is outlined to the west by the Blanquilla (1430 m), Merinos (1306 m) and Cañete (999 m) mountains. Limestone crests outcrop in the interior of the basin, for example the mountains of Peñarrubia-La Camorra (725 m) and Ortegícar (963 m), but most of the surface of the basin is occupied by a flysch type, lowridged relief with a mean height between 400 and $500 \mathrm{~m}$. In spite of this rough landscape, coast-inland communications were possible by a number of natural crossings such as "Puerto de las Atalayas" (Granado stream, Ardales) and the pass of Málaga (Arroyo de las Cañas, Carratraca). The passing from the east to the west is not difficult, as the Almargen-Guadalete valleys connect the bays of Cádiz and Málaga. The main drainage web is represented by the Guadalhorce River and its tributaries in the right margin, Turón and Guadalteba, which intersect in the vicinity of the reservoirs that supply water to Málaga.

The karst complex of Las Palomas cave ranges in altitude between 470 and $430 \mathrm{~m}$, showing a sharp fall at La Venta River, which riverbed cuts the limestone massif of Sierra de Teba-Peñarrubia and connects the Atlantic and Mediterranean basins by a natural corridor in the Guadalteba County. This karst complex is developed in limestone sediments of the inner Subbetic (Cruz-Sanjulián, 1974), showing a thick calcareous series of Jurassic age composed by red colored nodular and brechoid limestones dated to the Malm, followed by Cretaceous and Paleogene marly limestones with abundant flint nodules. The stratigraphic column finishes with the Upper Cretaceous (Coniacian-Maastrichtian) "red beds" characteristic of the Betic Chain. Andalusian-Germanic facies of Triassic age (Manto de Antequera-Osuna) are found below the Jurassic sediments and above the Paleogene levels. To the top of the series, there are bioclastic calcarenites, conglomerates and marls dated to the Late Miocene. Finally, among the Quaternary sediments there are a number of alluvial paleoterraces and travertines. The later were dated with ${ }^{14} \mathrm{C}$ at La Venta River to $8872 \pm 151 \mathrm{BP}$ by Cruz-Sanjulián (1981), who estimated a mean rate of $0.5 \mathrm{~mm} / \mathrm{y}$ for the fitting of the hydrographic net during the Holocene.

The cave was developed in the east margin of La Venta River, in a gorge known as "Tajo del Molino", reaching a height above the riverbed of several tens of meters. The gorge is an epigenic valley which resulted in a spectacular canyon-fan valley. During the
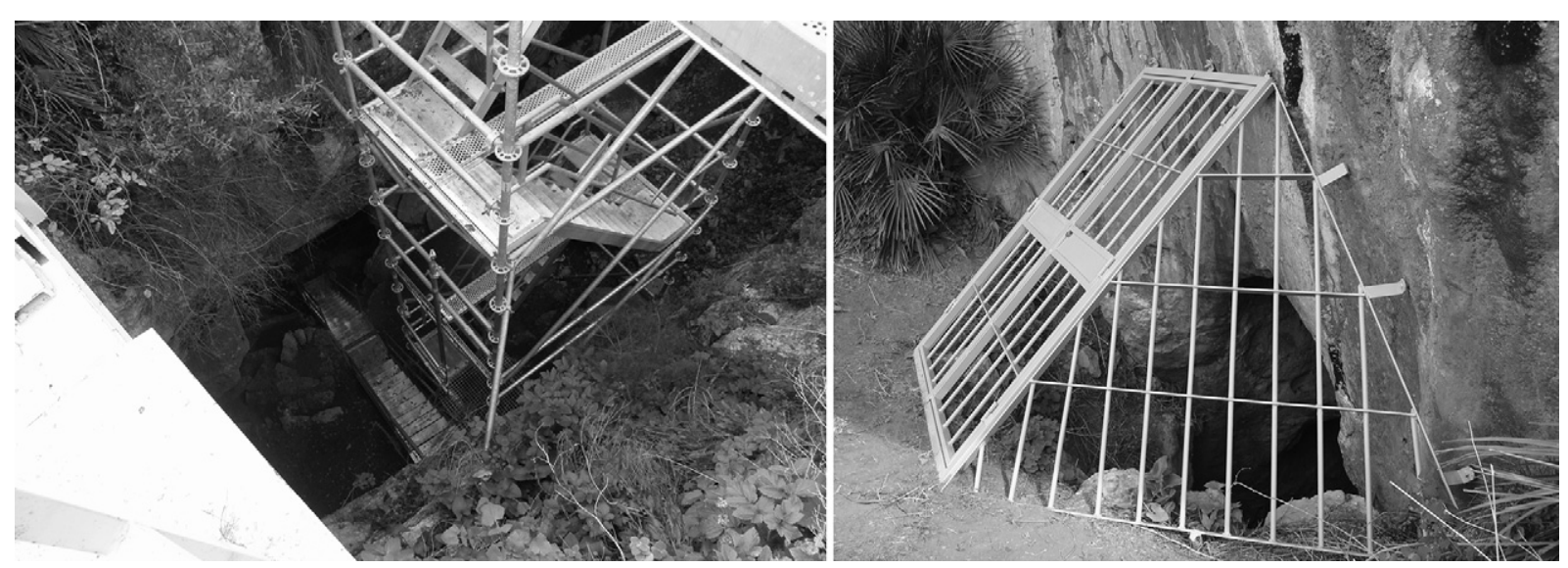

Fig. 4. Security structure in the entrance of the karst complex and closing of the "Sima". 
Early-Middle Miocene, a compression stage resulted in the structuring of the Inner Subbetic, followed by several distensile phases (transgressions). Later, during the Messinian, the final uprising of the region took place. In what concerns the cave, it was formed by the karstification of Sierra de Teba and includes a collapsed doline as well as several galleries that are not particularly rich in speleothems (which would clarify doubts on Pleistocene paleoclimatology). Above the speleothems there is a horizon of clays and debris, followed by a cemented breccia of limestone blocks and, above all, a level with large fallen blocks.

\section{Topography and location of findings}

A topographic chart of the cave was developed for referencing the superficial finds as well as all stratigraphic and sedimentological data. This provided new perspectives for understanding the development of the karst complex. The geomorphology of the cave, which dimensions are $100 \mathrm{~m}$ long by up to $20 \mathrm{~m}$ wide, imposed a longitudinal layout with a total of 18 points from the Sima to the exit to Tajo del Molino.

The walls of the Sima, with a depth of $9 \mathrm{~m}$, are composed of limestone for more than two-thirds, and the rest of the outcropping surface shows a sedimentary profile. Behind this chasm, the doline goes down with a marked drop to the present entrance, reaching a surface of around $600 \mathrm{~m}^{2}$. The space named "Gallery" is a geological nexus with the rest of the karst complex, although the presence of fallen blocks prevents the communication between these spaces.

Gallery 2, located in front of the former, was an unknown space, as it was clogged with debris and garbage. The current inlet (i.e., the old doline), has dimensions of $10 \times 5 \mathrm{~m}$, and the detachment of its walls was the origin of the chaotic blocks in the central area of the complex. This area, named "Cavidad-Cueva de las Palomas", has a dimension of about $30 \mathrm{~m}$ and is characterized, along with the blocks mentioned above, by a steep slope. Intense pillaging is evident in this zone, which ends in two side galleries of lobular morphology. A wide opening of $3 \times 4 \mathrm{~m}$ between these galleries forms the output of the karst complex, with flared downward limestone steps and numerous fractures. Inside this gallery there is an interesting outcrop of sedimentary breccias, clays and silts, which is worth studying geomorphologically and must be dated.

In broad terms, eight major outcrops have been identified to date in the karst complex. The sediments located in the part named as zone 9 have a residual nature and are sheltered in hovels. They are located at different heights, showing significant differences: those that outcrop at higher heights are light orange colored, fine-grained and strongly cemented in a patinated stone. The sediments at the bottom, very destroyed by pillaging, are darker, have a loose texture with few pebbles, and preserve coal with microfaunal remains. The following outcrop is near the entrance of the cave, with dimensions of $1.5 \mathrm{~m}$ width and $1.2 \mathrm{~m}$ height. It is located inside a hovel and may correspond to the blocks fallen from the roof, preserved in this place. These sediments show a well-developed calcareous concretion, with fractures that reveal the presence in the sediment of abundant osseous remains and gastropod shells that overlap heavily weathered speleothems. The third outcrop is in a small gallery of $3 \times 2 \mathrm{~m}$, which opens to the right wall of the "Cavidad-Cueva". These sediments are red, compact and fine-grained, showing skeletal remains interspersed with medium-sized blocks. The fourth area, with dimensions of $15 \times 8 \mathrm{~m}$ and placed also on this wall, shows a downward slope toward the center of the cavity and is partially filled with the fallen blocks. The sediments, beige and fine-grained, preserve a low density of skeletal remains and are covered by guano.

The last four areas are close to the exit to Tajo del Molino. The first of them stands out by its hardness and has a shape adapted to the space between two blocks. The sediments, beige, have bones and probably also lithic products that are not clearly identifiable. The sediments of the second area are very compacted and are leaned against the left wall of a large erosional rocky meander in the place named as zone 16. These sediments are reddish-orange, showing skeletal remains and some lithic products. With a steep slope to the Tajo del Molino, there are also fragments of large-sized speleothems among the small clasts. In the vicinity of this area there is a $0.7 \mathrm{~m}$ wide and $1.2 \mathrm{~m}$ high hovel with a similar structure to the one placed at the cave's entrance. The sediments of this shelter, dense and fine-grained, are stained by a strong calcareous concretion that prevents study and are surrounded by mediumsized blocks. Inside these sediments there are sandstone blocks from outside the karst complex, which are also present at the top of the mountain. The last outcrop is formed by an orange compacted breccia, which adapts to the space between a number of large limestone blocks and a left wall which preserves the flow of sediments that go down to the Tajo del Molino. This breccia preserves skeletal remains, lithic products and limestone materials with little wear and sharp edges.

\section{Lithic tools}

Cleaning works in Las Palomas documented the archaeological record from this karst complex, which in turn resulted in a better socialization of the site. The finding of lithic products preserved in situ at several points of Gallery, Gallery 2, Sima and Cueva de las Palomas provides a new historical dimension to these deposits and anticipates an interesting future for the continuity of this research. Here, a preliminary approach to the study of the lithic products, using the S.L.A. nomenclature (Carbonell et al., 1992, 1999) is presented, describing the retouched tools with the use of analytical typology (Laplace, 1975, 1985-1987).

Among the lithic products in stratigraphic connection that have been documented from cleaning works in the Sima, the following may be emphasized:

- BN2G-R21nokp, knapped on gray flint and little rounded, on BP-LE, with a multifaceted platform heel (Fig. 5,2). Typometrically, it is a flake of medium size (Bagolini, 1968).

- BP-LE, knapped on gray flint with a beige patina, showing an unifaceted platform heel and preserving sediments from the original deposit (Fig. 6,4).

- A BP series of LE and I type, with heels in smooth and multifaceted platform, in gray flint, and several specimens showing a beige patina. Most of them are flakes, although some bladelets are also found. Typometrically, medium-sized flakes and laminar bladelets are documented.

In the Gallery and Gallery 2 zones, there are BN1G-CM, BP-I and BP-LE, some of them obtained with the Levallois knapping technique. They are made on flint, with heels and marks of heating domes resulting from thermal alteration (Fig. 6,3).

Inside the cave, in the zone of the large solifluction flow, there are numerous breccia deposits in the lateral walls with lithic products linked to the periods in which the cavity was occupied. On the one hand, these data confirm the settlements of tribal societies during the early and recent prehistory, as suggested by the research team that studied the cave during the 1970s and 1980s (Ferrer and Marques, 1978; Baldomero, 1978; Aguado and Baldomero, 1979; Ferrer and Fernández, 1988). On the other, documented lithic products may be ascribed to the Mode III technotypological complex, especially those recovered from zone 12 , with tools embedded in the breccias that may be ascribed to BP-SD, BPI-, BP-LE (Fig. 6) as well as BN2G-D21 and D23, and also some BN2G-R21 tools, made on flint and other raw materials. In other parts of Cueva de Palomas, for 
example zones 16 and 17, lithic products that may be ascribed to this technotypological complex have been also documented from breccified areas. This allows development of a preliminary synthesis on the new records documented in stratigraphic position and during the cleaning works of the Las Palomas karst complex.

Flint is the basic raw material for knapping, with some tools made on other lithologies. The tools are gray and show diverse patinas, in most cases in light beige tones. Technologically, the artifacts are linked to the Mode III complex (Carbonell and Mosquera, 2000), showing a relationship in the knapped products that tends to conform Indirect Technical Operative Themes for extracting BP and, later, for shaping BN2G. In this way, the morphotechnical analysis allows documentation of the exploitation of raw materials and the production of BN1G, with the presence of a multipolar centripetal type (Fig. 6,1). The lithic tools from Sima, Gallery and Gallery 2, as well as those from the sedimentary breccias of Cueva de las Palomas, show processes of production or Technical Operational Units of exploitation and configuration. As in other sites with a Mode III technological record, Technical Operational Themes characterized by the extraction of lithic products resulting from centripetal knapping have been documented in this karst complex.
There is a clear technological correspondence between BN1G and BP. The types corresponding to the beginning of knapping activities, internal and Levallois are all documented (Fig. 6, 2-4). The latter are the logical consequence of the work of centripetal Indirect Technical Operative Themes. Smoothing is of great quality, with centripetal and longitudinal trends in the flakes. Bladelets are also documented. Concerning the typometries, there is a predominance of flakes, with some laminar flakes of medium size (Bagolini, 1968). Flakes with platform heels show the transformation of unifaceted types, but bifaceted and multifaceted ones are also present. Delineations are straight, convex and concave, showing an evident correspondence with the percussion planes of the BN1G cores. There are tools of Acheulean tradition among the retouched products, with evidence of BN1GC pebbles and bifacial artifacts. Tools with simple retouches predominate, but there is also evidence of the group of BN2G scrapers and some very characteristic types (R21, R23) in this settlement (Fig. 5,1-2). The rest of retouched products are mainly of the denticulate group, BN2G notches and denticulates (D21, D23). Retouched tools are basically made on BP-Levallois bases and show multifaceted platform heels.

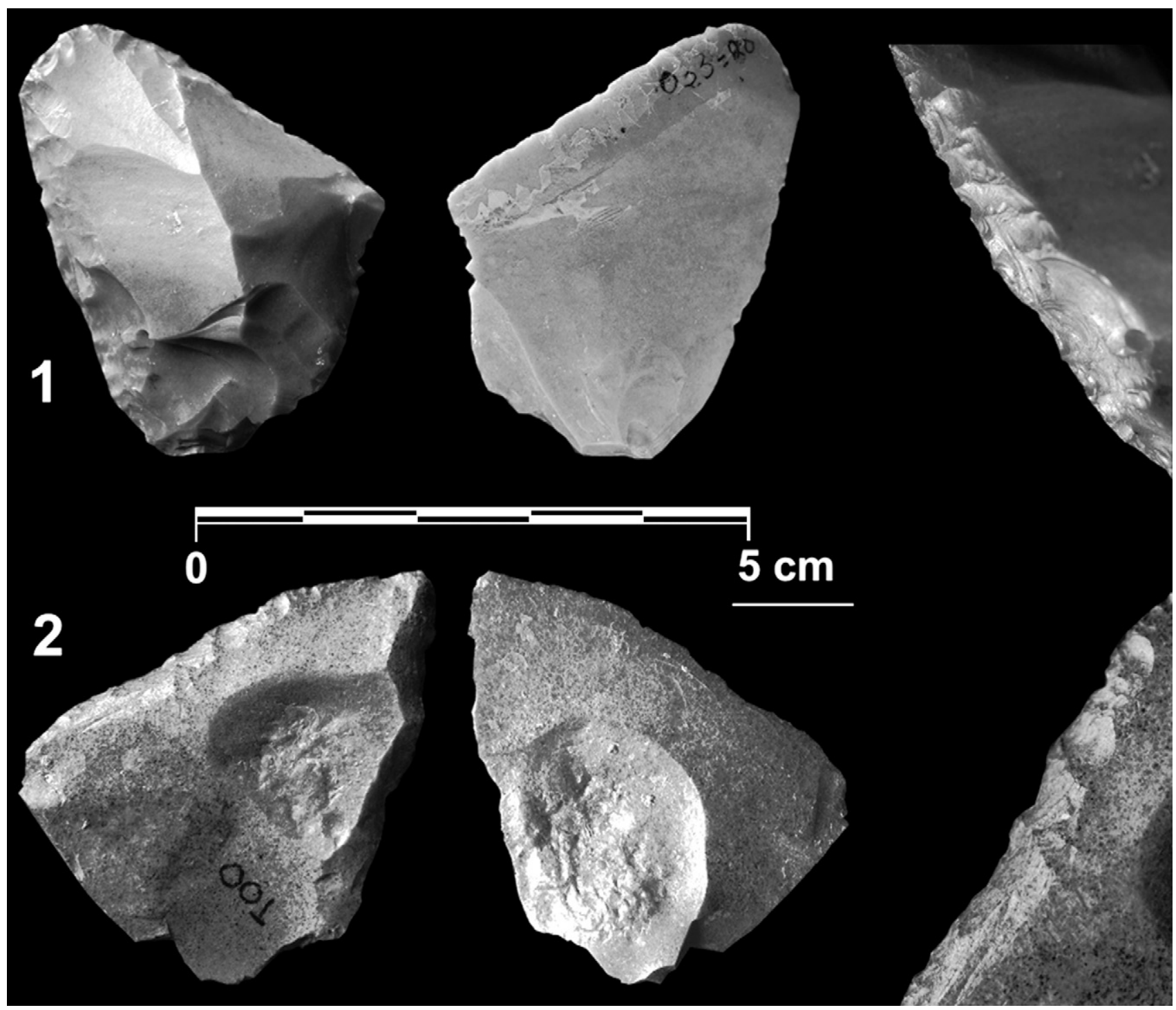

Fig. 5. 1: BN2G-R23nokp; 2: BN2G-R21nokp. A characteristic example of BN2G-R23nokp in flint with a beige colored patina on BP-LE and a convex faceted heel is shown (Fig. 5,2). 


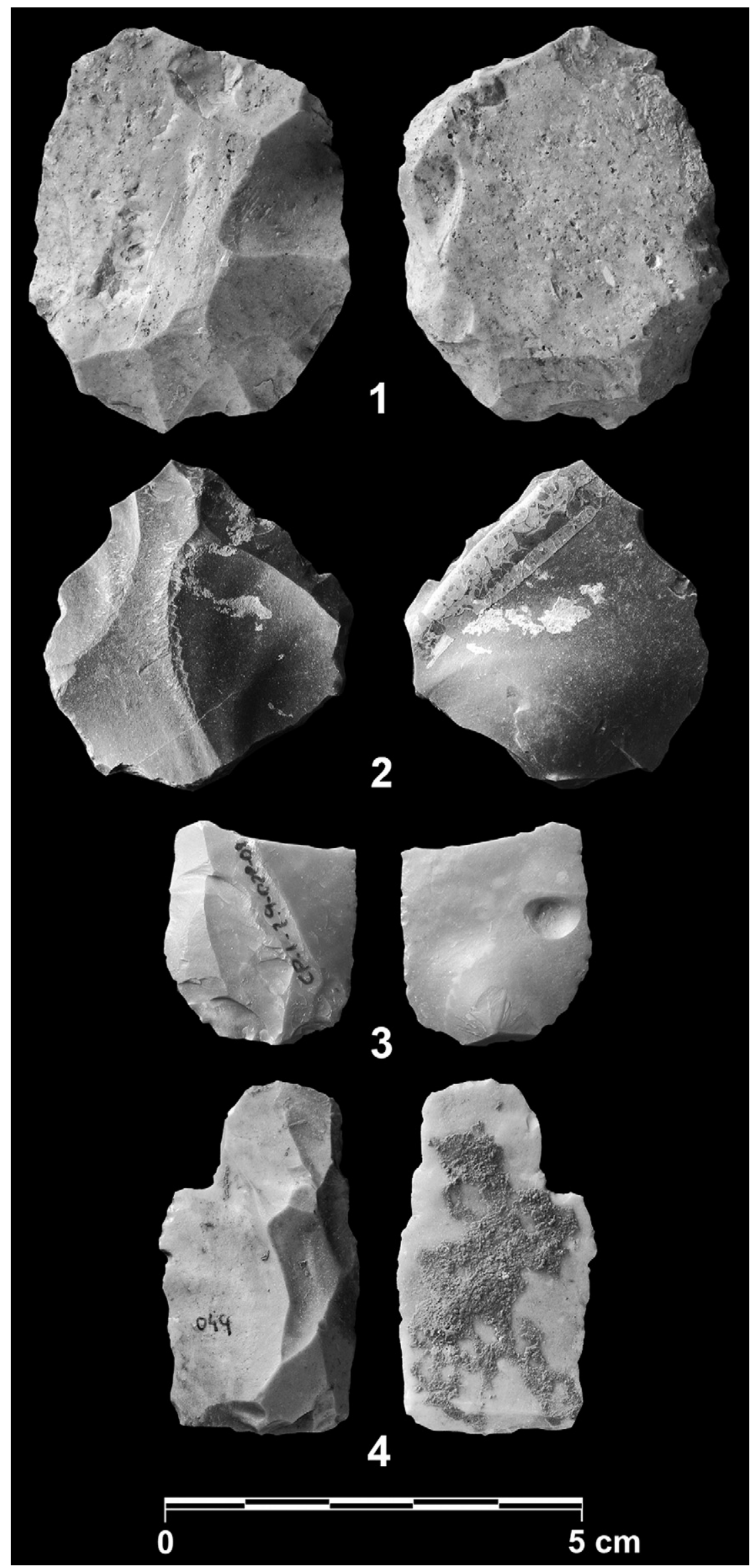

Fig. 6. 1: BN1G-CM; 2-4: BP-LE. 


\section{Large mammal remains}

Cleaning works in the karst complex have provided a relatively small but significant collection of large mammal remains that allows a new view on the fossil record of this archaeological site and its potential for studying the faunal assemblages preserved in the sedimentary deposits in depth. Faunal remains have been documented in situ within the Pleistocene sediments from Gallery, Gallery 2, Sima and Cueva de las Palomas (Fig. 7). Although most skeletal remains show a high degree of bone-fracturing, those bone specimens that preserve diagnostic parts allow estimating the presence of at least five large mammal species, including rhino Stephanorhinus cf. hemitoechus, red deer Cervus elaphus, wild boar
Sus scrofa, Spanish ibex Capra pyrenaica and lynx Lynx cf. pardina spelaea.

The rhino is represented by a right calcaneus preserved almost complete (CP-L-Z10.9-004-07) from an adult individual. The red deer is the species that provided more identifiable skeletal elements, one lower tooth (CP-L-Z12.2-096-08) and seven bone fragments, including a distal fragment of humerus (CP-L-Z10.1-009-08), a proximal (CP-L-Z9-015-07), and a distal (CP-L-Z9.2-002-07) radius fragments, a distal fragment of femur with carnivore gnaw-marks on the epiphysis (CP-L-GA-008/009-08), a diaphyseal fragment of tibia (CP-L-Z9.1-008-07), an astragalus (CP-L-Z9.1-013-09) and a diaphyseal fragment of metapodial (CP-L-S-065-07). The goat is the next most abundant species, with seven specimens that include a lower

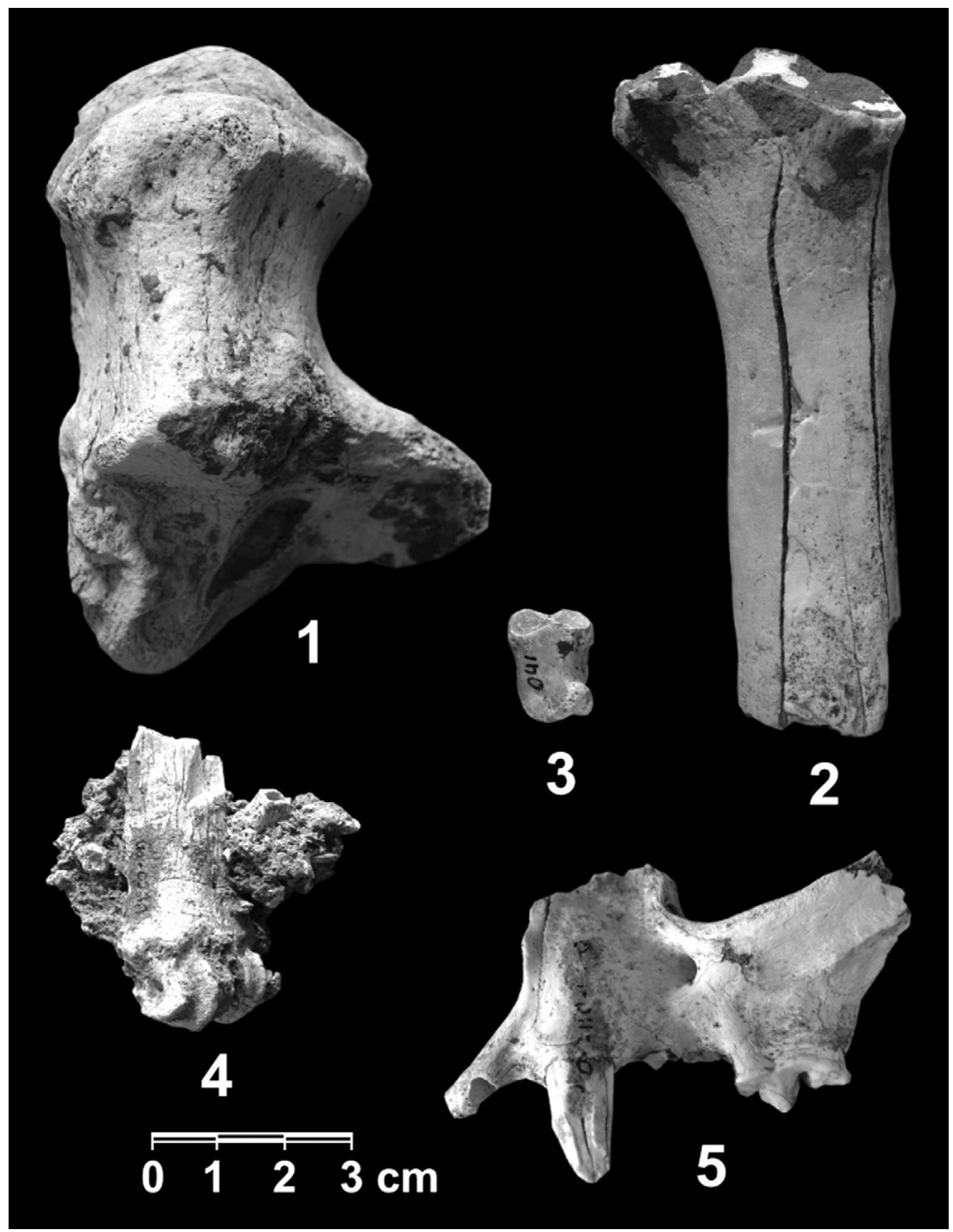

Fig. 7. Large mammal remains from "Cueva de Las Palomas de Teba". 1: Stephanorhinus cf. hemitoechus, complete right calcaneus from an adult individual. 2: Cervus elaphus, proximal end and diaphyseal fragment of a right radius from an adult individual. 3: Sus scrofa, complete second phalanx from an adult individual. 4: Capra pyrenaica, distal end and diaphyseal fragment of III-IV metacarpal from an adult individual. 5: Lynx cf. pardina spelaea, left hemimaxilla with the canine and carnassial from an adult individual. 
cheek tooth (CP-L-Z12.2-094-08), a fragment of scapula (CP-L-GA028-08), a distal metacarpal fragment (CP-L-GA-021-1-07), a midshaft (CP-L-GA-026-08) and a distal (CP-L-GA-027-08) tibia fragments, a first (CP-L-GA-028-08) and a second (CP-L-Z17.1-042-09) phalanges. The wild boar is represented by two bone fragments, a proximal end of tibia (CP-L-Z14.2-011-08) and a second phalanx (CP-L-Z17.1-041-09). Finally, the lynx was identified by a single skeletal element, a left maxilla from an adult individual (CP-L-Z9011-07) that preserves the canine and the upper carnassial (Fig. 7). According to the dimensions of the carnassial, which is similar to those of other specimens from Pleistocene L. pardina spelaea (see Werdelin, 1981), for example the one from the Trinchera-Galería site in Atapuerca (García and Arsuaga, 1998: Fig. 3), this maxilla may be tentatively assigned to this taxon (Fig. 8).

The presence of skeletal elements from several species of large mammals inside the karst complex of Las Palomas does not explain if these bone specimens were the result of anthropic activities or originated from natural causes (e.g., a carnivore denning site or a natural trap). However, the absence of cut-marks on the surface of the bones made for disarticulating and defleshing the carcasses, as well as the absence of percussion marks indicating bone-fracturing activities (which would indicate that these skeletal remains were consumed by humans) may be tentatively interpreted as indicating that the presence of faunal remains resulted from falls of animals or even that the bone specimens were transported inside the cave as complete carcasses or anatomical parts by water currents. The fact that several bones show gnaw-marks opens the possibility that the large Quaternary scavenging carnivores (e.g., the spotted hyenas) went down to the chasm to consume the carrion from dead animals or even used the cave as a breeding lair, transporting the mammal remains inside to feed their cubs. For this reason, until an exhaustive excavation is made and detailed

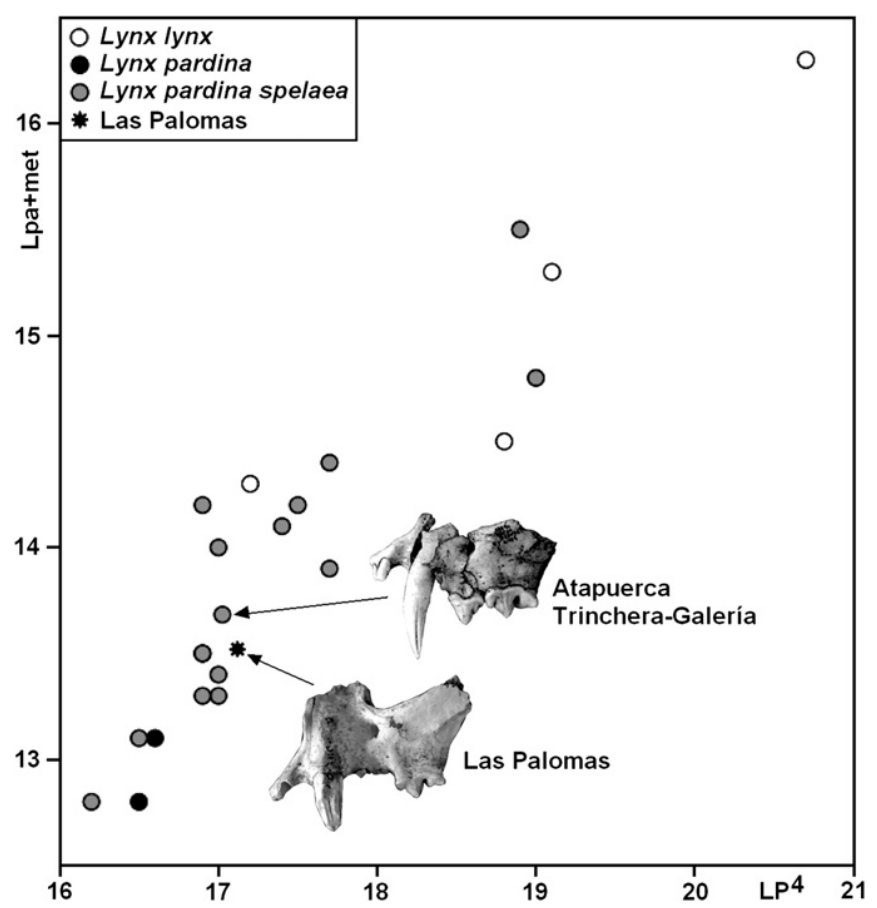

Fig. 8. Bivariate plot showing the relationship between the mesiodistal length of the upper carnassial $\left(\mathrm{LP}^{4}\right)$ and the sum of the lengths of the paracone and metastyle of $\mathrm{P}^{4}$ in the living Iberian lynxes (Lynx pardina) and European lynxes (Lynx lynx), as well as in several Pleistocene populations (Lynx pardina spelaea). Metric data from Werdelin (1981) and García and Arsuaga (1998). taphonomic studies of the bone assemblages preserved in the karst complex are developed, there are no definitive criteria to affirm if the presence of fossil remains is the result from scavenging activities of carnivores, from falls of animals in the chasm, or from human hunting.

\section{Interests for future research}

The karst complex of Las Palomas de Teba is in a physical environment that allowed the mobility of human groups over a natural landscape rich in raw materials and fauna. The presence of lithic products in the surface of the cave deposits has provided evidence of human settlements that may be connected with the sequences documented in the terraces of the low basin of the Guadalteba River (Morgado, 1995; Medianero et al., 2005, 2006a, 2006b). This allows proposing a direct relationship between the social territory of the populations that occupied the karst complex of Las Palomas and those human settlements located downstream. Given that the distance between both sites is less than $4 \mathrm{~km}$, the river valley and the Sierra de Teba-Peñarrubia mountains would be the territories prospected by these populations for obtaining lithic materials, prey resources and vegetal foodstuffs (Ramos, 1997, 1998, 1999, 2000a, 2000b, 2003; Richards et al., 2008; Medianero, 2009; Nowell and Horstwood, 2009). The opportunities that nature offers in this area for seasonal mobility (Cantalejo and Espejo, 1998; Cantalejo et al., 2006) probably allowed the movement of populations from the valleys of the Guadalteba and Turón rivers to the Atlantic (Ramos, 2008; Castañeda, 2008) and Mediterranean fringes (Cortés and Simón, 2001; Cortés, 2005, 2007a, 2007b; Cortés et al., 2008), as well as between these valleys and the nearby zones of the inner Subbetic (Barroso, 2003; Barroso and De Lumley, 2006; Botella et al., 2006; Medianero, 2009). In this context, the Guadalteba area and the central basin of the Guadalhorce River has a significant dimension in time and space for integrating the physical environment and socializing the territory during the Pleistocene epoch. The quality and abundance of the lithic products documented during the cleaning of the karst site, among which a number were localized in situ within sedimentary breccias that may be ascribed to the Middle and Late Pleistocene, opens interesting research avenues for studying the human populations that developed the Mode III technocomplex in this region of Southern Iberia. However, their stratigraphic, ecological and technological context is in direct relation with the records from other nearby areas. These areas include the terraces of the stream "arroyo del Agua" and Corbones River (Fernández, 2008), taking also into account the existence of ancient riverbeds (Medianero, 2009), the cave of Ardales (Cantalejo et al., 2003) and the archaeological finds in the high basin of the Guadalhorce River (Medina and Barroso, 1991) and even some near areas such as the Axarquía in Málaga (Ramos, 1988), the area of Zafarraya (Barroso, 2003 ) or the Subbetic in Córdoba (Botella et al., 2006). In addition, there are possible connections of these populations with the North African area (Ramos, 2006; Ramos and Bernal, 2006; Ramos et al., 2008a,b).

Therefore, the knowledge of this karst complex opens interesting perspectives on the possibility of studying a locality with sedimentary deposits of high stratigraphic completeness, an archaeological sequence, faunal remains, technology and evidence of human settlements in the central zone of the Province of Málaga. The finds in this site document the use and occupation of the territory, which may allow proposing hypotheses on social behavior, mobility and resource acquisition in mountainous landscapes, rivers, valleys and all types of endorheic environments (Ramos, 1988) located in the basin of the Guadalteba River (Medianero, 2009). 


\section{Acknowledgments}

We thank Consejería de Cultura (Junta de Andalucía) for approving this project and Guadalteba Consortium and Andalusian Employment Service (SAE) for financing it. The following students of the archeology workroom of "Escuela Taller Parque Guadalteba" helped during field and laboratory work: Carmen Palmero, José Mora, Juana García, Gema Crespillo, Esther Baeza, Rocío García, Ana Maldonado, Emilia Martínez, Noelia Mesa, Yolanda Pinta, Manoli Ponce, Fabiola Ríos, María Anaya, Ana Galván, Miguel García, Sandra Mateo, Virginia Montesino, Lidia Rosado, Cándida Sayago, Ana Capitán, Melody Romero, Sonia Martín, Marina Mesa, Rocío Pendón, Inmaculada Anaya, Gema Avilés, Isabel García, Laura Gallardo, Sara Guerrero, Carmen Jiménez, Celeste Jurado, Nieves Pinta, and operators Borja Valencia, Rafael Camacho and Javier Perea. This research was conducted under Spanish Ministry of Sciences projects CGL08-04896 to PP and CGL2009-08827 and CGL201015326 to BMN.

\section{References}

Aguado, T., Baldomero, A., 1979. Estudio de los materiales de superficie de la Cueva de las Palomas (Teba, Málaga). Mainake 1, 29-59.

Bagolini, B., 1968. Ricerche sulle dimensioni dei manufatti litici prehistorici non ritoccati. Annalli dell'Universitá di Ferrara XV (10), 195-219.

Baldomero, A., 1978. Noticias del hallazgo de un vaso eneolítico. Baetica 1, 167-170.

Barroso, C., 2003. El Pleistoceno Superior de la Cueva del Boquete de Zafarraya. Arqueología, Monografias Junta de Andalucía, Sevilla.

Barroso, C., De Lumley, H., 2006. La Grotte du Boquete de Zafarraya. Málaga, Andalousie. Consejería de Cultura, Junta de Andalucía, Sevilla.

Botella, D., Barroso, C., Riquelme, J.A., Abdessalok, S., Caparrós, M., Verdú, L., Monge, G., García, J.A., 2006. La Cueva del Ángel (Lucena, Córdoba), un yacimiento del Pleistoceno Medio y Superior del Sur de la Península Ibérica. Trabajos de Prehistoria 63, 153-165.

Cantalejo, P., Espejo, M.M., 1998. Arte rupestre paleolítico del sur peninsular. Consideraciones sobre los ciclos artísticos de los grandes santuarios y sus territorios de influencia. Revista Atlántica-Mediterránea de Prehistoria y Arqueología Social 1, 77-96.

Cantalejo, P., Maura, R., Espejo, M., Ramos, J., Medianero, J., Aranda, A., Mora, J., Becerra, M., Castañeda, V., 2003. Sobre los temas, las técnicas de ejecución y representación del arte paleolítico conservado en la Cueva de Ardales (Málaga). Pliocénica 3, 54-61.

Cantalejo, P., Maura, R., Espejo, M., Ramos, J., Medianero, J., Aranda, A., Durán, J.J., 2006. La Cueva de Ardales: arte prehistórico y ocupación en el Paleolítico Superior. CEDMA, Diputación Provincial de Málaga.

Castañeda, V., 2008. El primer poblamiento humano de la serranía de Ronda y su relación con el campo de Gibraltar. Mainake XXX, 331-344.

Carbonell, E., Mosquera, M., Ollé, A., Rodríguez, X.P., Sala, R., Vaquero, M., Vergés, J.M., 1992. New elements of the logical analytic system. In: First International Meeting on Technical Systems to Configure Lithic Objects of Scarce Elaboration. Cahier Noir, vol. 6, pp. 5-61.

Carbonell, E., Márquez, B., Mosquera, M., Olí, A., Rodríguez, X.P., Sala, R., Vergès, J.M., 1999. El Modo 2 en Galería. Análisis de la industria lítica y sus procesos técnicos. In: Juan Fernández-Lomana, C.D., Rosas-González, A., Carbonell, E. (Eds.), Atapuerca: ocupaciones humanas y paleoecología del yacimiento de Galería. Arqueología en Castilla y León, Memorias, vol. 7, pp. 299-352.

Carbonell, E., Mosquera, M. (Eds.), 2000. Las claves del pasado: la llave del futuro. Arola, Tarragona.

Cortés, M., 2005. El extremo occidente neandertal. El Paleolítico Medio en el Sur de la Península Ibérica. Neandertales cantábricos, estado de la cuestión. Monografías Museo de Altamira 20, 55-74.

Cortés, M., 2007a. La evolución en mosaico. El tránsito del Paleolítico MedioSuperior en el Sur de la Península Ibérica. Perspectiva desde una tesela. In: Cabrera-Valdés, V., Bernaldo, F., Maillo, J.M. (Eds.), En el Centenario de la Cueva de El Castillo: el ocaso de los Neandertales, pp. 145-164.

Cortés, M., 2007b. Cueva Bajondillo (Torremolinos). Secuencia cronocultural y paleoambiental del Cuaternario reciente en la Bahía de Málaga. CEDMA, Diputación Provincial de Málaga.

Cortés, M., Simón, M.D., 2001. Cave Bajondillo (Torremolinos, Málaga, Andalucia): news of the transition between the Middle and Upper Paleolithic in the South of Iberian Peninsula. Les premiers hommes modernes de la Peninsule iberique. Actes du Colloque de la Commision VIII de I'UISPP. 103-115.

Cortés, M., Morales, A., Simón, M.D., Bergadà, M.M., Delgado-Huertas, A., LópezGarcía, P., López-Sáez, J.A., Lozano-Francisco, M.C., Riquelme, J.A., Roselló, E., Sánchez-Marco, A., Vera-Peláez, J.L., 2008. Palaeoenvironmental and cultural dynamics of the coast of Málaga (Andalusia, Spain) during the upper Pleistocene and eEarly Holocene. Quaternary Science Reviews 23-24, 2176-2193.
Cruz-Sanjulián, J., 1974. Estudio geológico del sector Teba-Cañete La Real-Osuna (Cordilleras Béticas, región Occidental). Ph.D. Thesis Dissertation, University of Granada.

Cruz-Sanjulián, J., 1981. Evolución geomorfológica e hidrogeológica reciente en el sector Teba-Cañete La Real (Málaga) a la luz de la datación de formaciones travertínicas. Boletín Geológico y Minero 92, 297-308.

Fernández, L.E., 1986. Tipología de la cerámica lisa de la Cueva de las Palomas (Teba, Málaga). Unpubl. Ms. Thesis. University of Málaga, Spain.

Fernández, J.J., 2008. Las industrias líticas paleolíticas del Bajo Guadalquivir: Río Corbones (y II). Carel 6, 2395-2497.

Ferrer, J.E., Marques, I., 1978. Avance de las campañas arqueológicas realizadas en la Cueva de las Palomas, Teba (Málaga). Baetica 1, 195-199.

Ferrer, J.E., Fernández, J., 1988. Avance al estudio de la industria en sílex de la Cueva de las Palomas (Teba, Málaga). Mainake 8-9, 5-14.

Fontao, M.M., 1986. La cerámica decorada de la Cueva de las Palomas (Teba, Málaga), técnicas y estilos. Unpubl. Ms. Thesis. University of Málaga, Spain.

García, N., Arsuaga, J.L., 1998. The carnivore remains from the hominid-bearing Trinchera-Galería, Sierra de Atapuerca, Middle Pleistocene site (Spain). Geobios 31, 659-674.

Laplace, G., 1975. La typologie analytique et structurale: base rationnelle d'étude des industries lithiques et osseuses. Colloques Nationaux CNRS 932. 91-141.

Laplace, G., 1985-1987. Un exemple de nouvelle écriture de la grille typologique. Dialekitkê, Cahiers de Typologie Analytique. 16-21.

Medianero, F.J., 2003. Informe de expolio en el yacimiento arqueológico de la cueva de Las Palomas (Teba, Málaga). Unpublished Report, Delegación de Cultura de Málaga.

Medianero, F.., 2007a. Estado actual en el acondicionamiento, cerramiento y limpieza en la Cueva de las Palomas de Teba (Teba, Málaga). Unpublished Report, Archivo de la Delegación de Cultura de Málaga.

Medianero, F.J., 2007b. Informe de intromisión, daño y robo en la verja de entrada a la Cueva de las Palomas de Teba. Málaga. Unpublished Report, Archivo de la Delegación Provincial de Cultura de Málaga.

Medianero, F.J., 2008. Informe de intromisión y expolio. Cueva de las Palomas de Teba. Unpublished Report, Archivo de la Delegación de Cultura de Málaga.

Medianero, F.J., 2009. Turismo y Patrimonio Arqueológico: la Comarca de Guadalteba. Ph.D. Thesis Dissertation, University of Málaga.

Medianero, F.J., Ramos, J., Cantalejo, P., Espejo, M.M., Maura, R., 2005. Evidencias de actividad prehistórica y nuevas estructuras romanas en las Eras de Peñarrubia, Parque Guadalteba (Campillos, Málaga). Mainake 27, 303-321.

Medianero, FJ. Ramos, J. Cantalejo, P., Espejo, M.M. Maura, R, Durán, JJ, 2006a. Grupos de cazadores-recolectores en la cuenca baja del río Guadalteba. Zonificación del área y aproximación a sus producciones y contexto social. In: Patrimonio Guadalteba, vol. 1. Parque Arqueológico Guadalteba, Campillos, Málaga. 9-25.

Medianero, F.J., Ramos, J., Cantalejo, P., Espejo, M.M., 2006b. Parque Guadalteba: desde la pertenencia al territorio hasta su domino y transformación del Paisaje. AKROS, la Revista del Museo 5, 93-102.

Medina, F., Barroso, R., 1991. Estudio tecnotipológico del yacimiento lítico de superficie de Cuarterones (Villanueva del Rosario, Málaga). Proyecto: Los yacimientos líticos de superficie del Alto Valle del Guadalhorce (Málaga, España). Bases para el estudio integral del poblamiento prehistórico de la zona. Segunda Campaña. In: Anuario Arqueológico de Andalucía, vol. II 50-58.

Morgado, A., 1995. La Prehistoria: las primeras sociedades. In: García, E., Martínez, V., Morgado, A. (Eds.), El Bajo Guadalteba (Málaga): espacio y poblamiento. Una aproximación arqueológica a Teba y su entorno. CEDMA, Diputación Provincial de Málaga, pp. 27-87.

Nowell, G.M., Horstwood, M.S.A., 2009. Comments on Richards et al., Journal of Archaeological Science 35, 2008, Strontium isotope evidence of Neanderthal mobility at the site of Lakonis, Greece using laser-ablation PIMMS. Journal of Archaeological Science 39 (7), 1334-1341.

Ramos, J., 1988. El poblamiento prehistórico del Alto Vélez hasta la Edad del Bronce. Diputación Provincial de Málaga.

Ramos, J., 1997. Disputados entre la Antropología y la Historia. Un acercamiento socioeconómico para el estudio de los cazadores-recolectores. Revista AtlánticaMediterránea de Prehistoria y Arqueología Social I, 7-32.

Ramos, J., 1998. La ocupación prehistórica de los medios kársticos de montaña en Andalucía. In: Durán, J.J., López-Martínez, J. (Eds.), Karst en Andalucía. Instituto Tecnológico Geominero de España, pp. 63-84.

Ramos, J., 1999. Europa prehistórica. Cazadores y recolectores. Editorial Sílex, Madrid.

Ramos, J., 2000a. Las formaciones sociales son mucho más que adaptación ecológica. Revista Atlántica-Mediterránea de Prehistoria y Arqueología Social III, $29-46$.

Ramos, J., 2000b. Las sociedades cazadoras-recolectoras: un balance historiográfico de sus formas de estudio en Europa. Boletín de Antropología Americana 36, $77-136$

Ramos, J., 2003. Metodología para el estudio de las comunidades cazadoras-recolectoras. Reflexiones en el ámbito del Estrecho de Gibraltar. In: Ramos, J., Bernal, D., Castañeda, V. (Eds.), El Abrigo y la Cueva de Benzú en la Prehistoria de Ceuta. Consejería de Educación y Cultura de Ceuta, UNED and Universidad de Cádiz, pp. 27-54

Ramos, J., 2006. Las sociedades cazadoras-recolectoras en el norte de África y sur de la Península Ibérica. Reflexiones sobre relaciones y contactos, desde los orígenes del poblamiento a los grupos portadores de tecnocomplejos de modo III. In: Bernal, D., Raissouni, B., Ramos, J., Bouzouggar, A. (Eds.), Actas del I Seminario Hispano-Marroquí de especialización en Arqueología, Cádiz, pp. 95-111. 
Ramos, J., Bernal, D. (Eds.), 2006. El Proyecto Benzú. 250.000 años de historia en la orilla africana del Círculo del Estrecho. 30 preguntas y 10 opiniones. Ciudad Autónoma de Ceuta y Universidad de Cádiz, Cádiz.

Ramos, J., 2008. Memoria del proyecto de investigación: la ocupación prehistórica de la campiña litoral y Banda Atlántica de Cádiz. Aproximación a estudio de las sociedades cazadoras-recolectoras, tribales-comunitarias y clasistas iniciales. Monografías de Arqueología. Junta de Andalucía, Consejería de Cultura.

Ramos, J., Pérez, M., Vijande, E., Cantillo, J.J., 2008a. Nuevas perspectivas en el estudio de las sociedades tribales comunitarias neolíticas en el área del Estrecho de Gibraltar. In: Ramos, J., Zouak, M., Bernal, D., y Raissouni, B. (Eds.), Las ocupaciones humanas de la cueva de Caf Taht el Ghar (Tetuán). Los productos arqueológicos en el contexto del Estrecho de Gibraltar. Colección de Monografías del Museo Arqueológico de Tetuán, vol. I. Universidad de Cádiz,
Diputación de Cádiz y Dirección Regional de Cultura Tánger-Tetuán del Reino de Marruecos, Cádiz, pp. 93-133.

Ramos, J., Bernal, D., Domínguez-Bella, S., Calado, D., Ruiz, B., Gil, M.J., Clemente, I. Durán, J.J., Vijande, E., Chamorro, S., 2008b. The Benzú rockshelter: a middle Palaeolithic site on the North African coast. Quaternary Science Reviews 27, 2210-2218.

Richards, M., Harvati, K., Grimes, V., Smith, C., Smith, T., Hublin, J.-J., Karkanas, P. Panagopoulou, E., 2008. Strontium isotope evidence of Neanderthal mobility at the site of Lakonis, Greece using laser-ablation PIMMS. Journal of Archaeological Science 35, 1251-1256.

Recio-Ruiz, A., 1993. Informe arqueológico del Término Municipal de Teba (Málaga). Anuario Arqueológico de Andalucía III, 413-418.

Werdelin, L., 1981. The evolution of lynxes. Annales Zoologici Fennici 18 37-71. 